\title{
Spinal cord injury epidemiological profile in the Sarah Network of Rehabilitation Hospitals-a Brazilian population sample
}

\author{
DC Barbetta ${ }^{1}$ TR Smanioto ${ }^{1}$ - MF Poletto ${ }^{1} \cdot$ RFA Ferreira $^{1} \cdot$ ACG Lopes $^{1} \cdot$ FM Casaro ${ }^{1} \cdot$ ACS Camargo $^{1}$. \\ TO Ogashawara ${ }^{1}$
}

Received: 18 September 2017 / Revised: 30 January 2018 / Accepted: 30 January 2018

(c) International Spinal Cord Society 2018

\begin{abstract}
Study design Retrospective cross-sectional study.

Objective To describe the epidemiological profile of individuals with spinal cord injury (SCI), who visited the Sarah Network in 2014.

Setting Brazil, Brasília-Federal District.

Methods A review of the electronic medical records of persons with SCI, aged over 15 years, was carried out.

Results The medical records of 2076 persons were evaluated: $83 \%$ were male, the mean age was 31 years, $40 \%$ did not complete elementary school, $67.7 \%$ had paraplegia, and $74.4 \%$ had complete SCI. The primary etiologies were gunshot wounds $(28.4 \%)$, motorcycle accidents $(24.6 \%)$, and motor vehicle accidents $(19.1 \%)$. In the comparative analysis between genders, differences were observed regarding the level of education and completeness of injury.

Conclusion Gunshot wounds were the main cause of SCI in our population, comprising mostly male individuals with thoracic injury, resulting in complete SCI. Data show a high incidence of SCI in young adults owing to violence in Brazil.
\end{abstract}

\section{Introduction}

Spinal cord injury (SCI) is a disabling condition causing profound disruption in sensory, motor, and autonomic functions. Traumatic SCI represents $80 \%$ of all cases [1]. An overall global incidence of 23 cases/million was estimated in 2007, and the worldwide prevalence ranges from 236 to 4187 /million [2, 3].

In developing countries, it is estimated that $82.8 \%$ (confidence interval, CI: 80.3-85.2) of SCI cases occur among males, with a mean age of 32.4 years (CI: 29.7-35.2). The leading causes were traffic accidents (41\%; CI: 35.4-47.4), followed by falls (34.9\%; CI: 26.7-43.1) [4]. Paraplegia represented $2 / 3$ of all cases, with an equal distribution of complete and incomplete lesions $[1,5]$.

The literature indicates the lack of studies related to SCI epidemiology in Latin America. In Brazil, there have not

DC Barbetta

dcbarbetta@sarah.br

1 Spinal cord injury Neurorehabilitation Unit, Sarah Network of Rehabilitation Hospitals, Brasília, Brazil been any national epidemiological surveys that describe the characteristics of this population. It has been estimated that the average incidence is 21 cases per million/year; [6] whereas, da Paz et al. found a prevalence of $8.6 \%$ in traumatic SCI. The mean age, among national studies, ranged from 30 to 35 years. Approximately $80 \%$ of the persons were male, and the most frequent cause of injury was traffic accidents [7]. However, other studies found falls, followed by car accidents as the main causes [6-8]. The most common level of injury was cervical (36.6-46.3\%), and $34-67 \%$ had complete SCI [6,9]. Given the scarcity of epidemiological information regarding the population with SCI at the national level, we believed that a review of persons with SCI at the Sarah Network of Rehabilitation Hospitals would contribute to Brazilian epidemiology data.

The Sarah Rehabilitation Center was inaugurated in 1960. Today, the Network comprises nine centers located throughout Brazil, seven of which have SCI rehabilitation programs (Brasília-2 units, Fortaleza, São Luiz, Belo Horizonte, Salvador and Rio de Janeiro). In total, > 19 million annual procedures are performed, using exclusively public resources to practice quality medical care in the rehabilitation field. The rehabilitation program for SCI admits adults with traumatic and non-traumatic lesions. In 
Table 1 Epidemiological profile of persons with SCI treated at the Sarah Network in 2014—comparative analysis between genders

\begin{tabular}{|c|c|c|c|c|c|c|}
\hline & & $N(\%)$ & $\begin{array}{l}\text { Total } \\
2076\end{array}$ & $\begin{array}{l}\text { Female } \\
342(16.5)\end{array}$ & $\begin{array}{l}\text { Male } \\
1734(83.5)\end{array}$ & $P$ value $^{\mathrm{a}}$ \\
\hline \multirow[t]{6}{*}{ Age } & \multirow[t]{2}{*}{ Years } & $\begin{array}{l}\text { Mean } \pm \\
\text { s.d. }\end{array}$ & $31.0 \pm 11.4$ & $30.0 \pm 11.0$ & $31.2 \pm 11.4$ & \\
\hline & & $\begin{array}{l}\text { Q2 } \\
\text { (Q1- } \\
\text { Q3) }\end{array}$ & $\begin{array}{l}28.5 \\
(22.3-37.4)\end{array}$ & $\begin{array}{l}26.6 \\
(21.4-37.1)\end{array}$ & $\begin{array}{l}28.8 \\
(22.3-37.4)\end{array}$ & \\
\hline & $16-30$ years & $n(\%)$ & & $209(61.1)$ & 969 (55.9) & 0.233 \\
\hline & $31-45$ years & & & $94(27.5)$ & $544(31.4)$ & \\
\hline & $46-60$ years & & & $36(10.5)$ & $190(11.0)$ & \\
\hline & $60+$ years & & & $3(0.9)$ & $31(1.8)$ & \\
\hline \multirow[t]{4}{*}{$\begin{array}{l}\text { Level of } \\
\text { education }\end{array}$} & $\begin{array}{l}\text { Incomplete elementary } \\
\text { school or illiterate }\end{array}$ & $n(\%)$ & $849(40.9)$ & $83(24.3)$ & $766(44.2)$ & 0.000 \\
\hline & $\begin{array}{l}\text { Complete elementary } \\
\text { school }\end{array}$ & & 427 (20.6) & $57(16.7)$ & $370(21.3)$ & \\
\hline & Secondary school & & $656(31.6)$ & $147(43.0)$ & $509(29.4)$ & \\
\hline & Post-secondary school & & 144 (6.9) & $55(16.1)$ & $89(5.1)$ & \\
\hline \multirow{3}{*}{$\begin{array}{l}\text { Level of } \\
\text { injury }\end{array}$} & Cervical & $n(\%)$ & $669(32.2)$ & 99 (28.9) & $570(32.9)$ & 0.232 \\
\hline & Thoracic & & $1257(60.5)$ & $213(62.3)$ & $1044(60.2)$ & \\
\hline & Lumbosacral & & $150(7.2)$ & $30(8.8)$ & $120(6.9)$ & \\
\hline \multirow[t]{6}{*}{ AIS } & A & $n(\%)$ & $1265(60.9)$ & $210(61.4)$ & $1055(60.8)$ & $0.003^{\mathrm{b}}$ \\
\hline & B & & $279(13.4)$ & $66(19.3)$ & $213(12.3)$ & \\
\hline & $\mathrm{C}$ & & $249(12.0)$ & $29(8.5)$ & $220(12.7)$ & \\
\hline & $\mathrm{D}$ & & $152(7.3)$ & $17(5.0)$ & $135(7.8)$ & \\
\hline & $\begin{array}{l}\text { Cauda equina/conus } \\
\text { medullaris }\end{array}$ & & $117(5.6)$ & $20(5.8)$ & $97(5.6)$ & \\
\hline & $\begin{array}{l}\text { Other medullar } \\
\text { syndromes }\end{array}$ & & $14(5.8)$ & $0(0)$ & $14(0.8)$ & \\
\hline
\end{tabular}

$N$ number, s. $d$ standard deviation, $Q$ quartile, AIS ASIA Impairment Scale

${ }^{\mathrm{a}} \mathrm{x}$-square $(p$ value $<0.05)$

${ }^{\mathrm{b}}$ Between genders when injuries were grouped as either complete (AIS A and B) and incomplete (C and D) lesion

2014, the Brasilia Unit served 814 individuals with SCI. The persons must be clinically stable to participate in the prescribed rehabilitation activities (http://www.sarah.br/enus/).

\section{Objective}

\section{Primary objective}

The primary aim of this study was to evaluate the epidemiological profile of the population with traumatic SCI that was treated at the Sarah Network in 2014.

\section{Secondary objective}

The secondary objectives were to perform a comparative epidemiological analysis of genders and the leading causes of SCI.

\section{Methods}

\section{Study design}

Retrospective cross-sectional study.

\section{Participants}

A review of the electronic medical records of persons with SCI aged over 15 years was carried out in 2014 in the Sarah Network (Brasília, Fortaleza, São Luiz, Belo Horizonte, Salvador, and Rio de Janeiro units). The database was provided by the quality control department of the Sarah Network of Rehabilitation Hospitals.

\section{Study variables}

A survey of the population distribution regarding gender, age at the time of injury, level of education, state of origin, 
Fig. 1 Distribution of the etiologies of the spinal cord injury by region of Brazil-A Sarah network survey, 2014

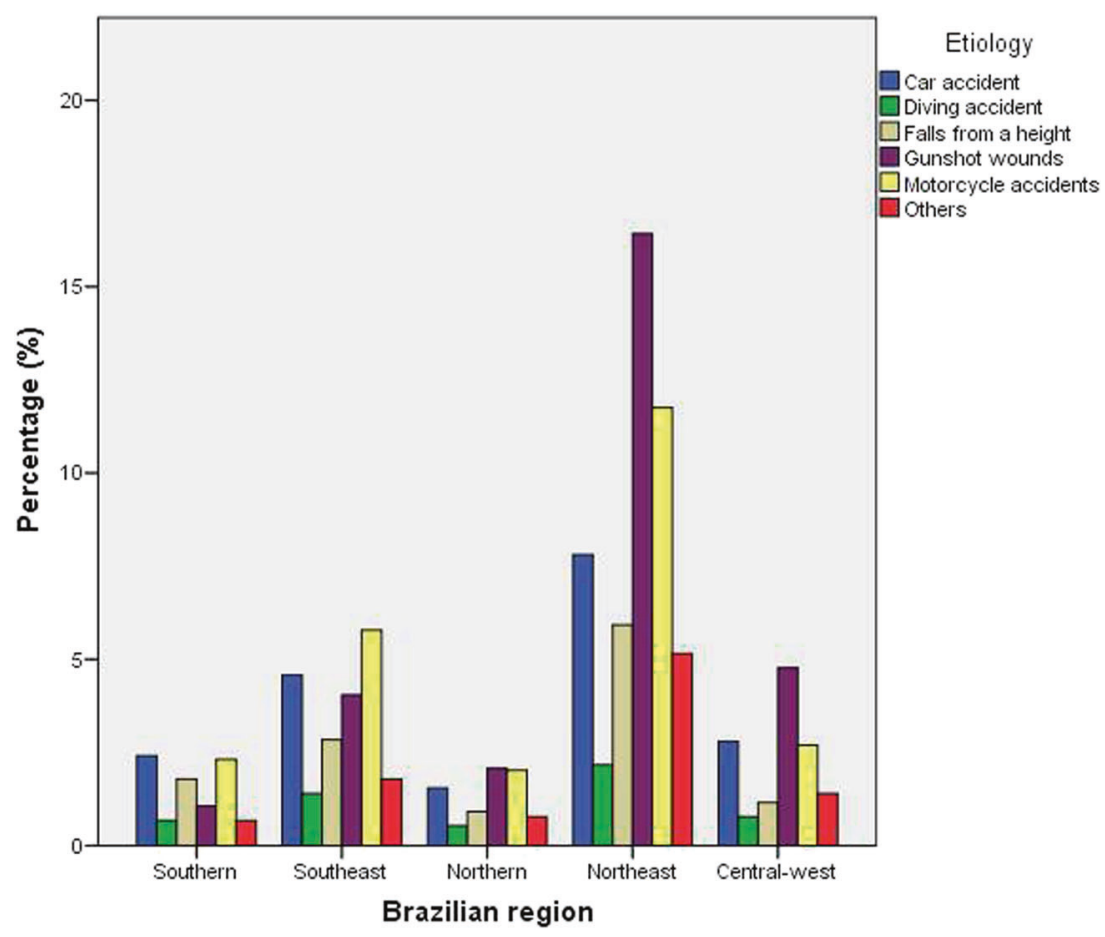

etiology, level, and completeness of the SCI was conducted. These data were assessed on admission by a physician and were collected retrospectively from the medical records. When data were missing in the physician's medical records, it was searched in physiotherapy/occupational therapy and social worker records. A comparative analysis between genders and between the three most frequent causes of SCI was carried out.

The data relating to the level and completeness of injury were assessed as recommended by the International Standards for Neurologic Classification of SCI by a physician. The level of SCI was classified into three groups-cervical, thoracic, and lumbosacral. For this review, individuals who showed differences in the neurological level between both sides of the body were classified using the more rostral level. Persons were classified according to the ASIA Impairment Scale (AIS); along with medullar syndrome status [9].

The level of education was divided into four groups: incomplete elementary school (or illiterate), complete elementary school, complete secondary school, and postsecondary school.

\section{Statistical analysis}

A descriptive analysis was performed, addressing the etiologic distribution of the SCI sorted by Brazilian regions: South, Southeast, North, Northeast, and Central-west (including the Federal District).
The $\chi^{2}$-test was used for the comparative analysis of the categorical variables of gender, educational level, etiology, level, and completeness of the injury. For statistical analysis, the persons were grouped into paraplegia and tetraplegia and complete (AIS A and B) and incomplete motor (C, D, $\mathrm{E}$, and medullar syndromes) lesions. We used the $\chi^{2}$-test when the age variable was expressed in categories (16-30, $31-45,45-60$, and $60+$ years) and the t-test when expressed as the mean \pm standard deviation (SD). The one-way analysis of variance was used to determine whether there were significant differences, with respect to age, and when the three main causes of SCI were compared. A $p$-value < 0.05 was considered significant. The Statistical Package for the Social Sciences, version 13.0 (SPSS Inc., Chicago, IL, USA) was used for data processing.

\section{Results}

Two thousand and seventy-six cases from the electronic medical records system of the Sarah Network Hospitals were evaluated. There were no missing data regarding the variables gender, age at the time of injury, level of education, state of origin, etiology, level, and completeness of the SCI.

Forty-nine percent of subjects were from Northeast region, followed by $20.4 \%$ from the Southeast, $13.6 \%$ from the Central-west, $8.9 \%$ from the Southern, and $7.9 \%$ from the Northern region of Brazil (Fig. 1). Eighty-three percent 
Table 2 Epidemiological profile of persons involved in car, motorcycle, and gunshot wound accident—comparative analysis

\begin{tabular}{|c|c|c|c|c|c|c|}
\hline & & & $\begin{array}{l}\text { Car } \\
\text { accident }\end{array}$ & $\begin{array}{l}\text { Motocycle } \\
\text { accident }\end{array}$ & $\begin{array}{l}\text { Gunshot } \\
\text { wounds }\end{array}$ & $P$ value \\
\hline & & $N$ & 397 & 510 & 598 & \\
\hline Gender & Male & $\%$ & 60.9 & 86.3 & 90.6 & $0.000^{\mathrm{a}}$ \\
\hline \multirow[t]{5}{*}{ Age } & Years & $\begin{array}{l}\text { Mean } \\
\pm \text { s.d. }\end{array}$ & $31.7 \pm 10.8$ & $30.7 \pm 10.6$ & $27.3 \pm 8.3$ & $0.000^{\mathrm{b}}$ \\
\hline & $16-30$ years & $n(\%)$ & $200(50.4)$ & $299(58.6)$ & $420(71.3)$ & $0.000^{\mathrm{a}}$ \\
\hline & $31-45$ years & & $148(37.3)$ & $155(30.4)$ & $143(24.3)$ & \\
\hline & $46-60$ years & & $45(11.3)$ & $53(10.4)$ & $25(4.2)$ & \\
\hline & $60+$ years & & $4(1.0)$ & $3(0.6)$ & $1(0.2)$ & \\
\hline \multirow[t]{4}{*}{$\begin{array}{l}\text { Level of } \\
\text { education }\end{array}$} & $\begin{array}{l}\text { Incomplete elementary } \\
\text { school or illiterate }\end{array}$ & $n(\%)$ & $103(25.9)$ & $185(36.3)$ & $273(46.3)$ & $0.000^{\mathrm{a}}$ \\
\hline & $\begin{array}{l}\text { Complete elementary } \\
\text { school }\end{array}$ & & $60(15.1)$ & 99 (19.4) & $151(25.6)$ & \\
\hline & Secondary school & & $163(41.1)$ & $198(38.8)$ & $148(25.1)$ & \\
\hline & Post-secondary school & & $71(17.89)$ & $28(5.5)$ & $17(2.9)$ & \\
\hline \multirow{3}{*}{$\begin{array}{l}\text { Level of } \\
\text { injury }\end{array}$} & Cervical & $n(\%)$ & $169(42.3)$ & $133(26.1)$ & $88(14.9)$ & $0.000^{\mathrm{a}}$ \\
\hline & Thoracic & & $202(50.9)$ & $354(69.4)$ & $445(75.6)$ & \\
\hline & Lumbosacral & & $27(6.8)$ & $23(4.5)$ & $56(9.5)$ & \\
\hline \multirow[t]{6}{*}{ AIS } & A & $n(\%)$ & $237(59.7)$ & $338(66.3)$ & $387(65.7)$ & $0.898^{\mathrm{a}, \mathrm{c}}$ \\
\hline & $\mathrm{B}$ & & $70(17.6)$ & $53(10.4)$ & $61(10.4)$ & \\
\hline & $\mathrm{C}$ & & $44(11.1)$ & $64(12.5)$ & $55(9.3)$ & \\
\hline & $\mathrm{D}$ & & 0 & 0 & 0 & \\
\hline & $\begin{array}{l}\text { Cauda equina/conus } \\
\text { medullaris }\end{array}$ & & $23(5.8)$ & $16(3.1)$ & $47(8)$ & \\
\hline & $\begin{array}{l}\text { Other medullar } \\
\text { syndromes }\end{array}$ & & 0 & $5(1)$ & $2(0.3)$ & \\
\hline
\end{tabular}

$N$ number, s.d. standard deviation, AIS ASIA Impairment Scale

${ }^{\mathrm{a}} \mathrm{X}$-square $(p$ value $<0.05)$

${ }^{\mathrm{b}}$ ANOVA $(p$ value $<0.05)$

${ }^{\mathrm{c}}$ Between three etiologies when injuries were grouped as both complete (AIS A and B) and incomplete (C and D) lesion

were male. Mean age was 31 years (SD: $11.37 ; 15.6-79.8$ years). Approximately $75 \%$ of the population was younger than 37.9 years. Forty percent of the persons did not finish elementary school, $31.6 \%$ completed secondary education and only $6.9 \%$ had post-secondary education (Table 1).

Predominant causes of SCI were gunshot wounds (28.4\%), motorcycle accidents (24.6\%), car accidents (19.1\%), falls from a height (12.6\%), and shallow water diving (5.5\%). Spinal cord injuries owing to physical aggression $(0.3 \%)$, trampling $(1.8 \%)$, sports $(0.4 \%)$, the impact of an object (3.9\%), and falls from standing height $(1.1 \%)$ were grouped. Gunshot wounds were more frequent in the Central-west, Northeast and North regions. In the Southeast, motorcycle accidents represented $40 \%$ of the cases (Fig. 1). Persons with paraplegia represented $67.7 \%$ of the population, whereas $74.4 \%$ presented with complete motor injury. Among the incomplete lesions (532 persons), $46.8 \%$ were classified as AIS C (Table 1).
Between genders, there was no statistical difference regarding age at injury or level of injury. Eighty-one percent of women and $73 \%$ of men sustained complete motor injuries $(p=0.003)$. Regarding the level of education, 59\% of women completed high school compared with $34.5 \%$ of men (Table 1).

Among the leading causes of SCI (car accident, motorcycle accident, and gunshot wound), differences were explored with respect to gender, age, level of education, and level of injury. The distribution of the complete and incomplete motor lesions was similar in all three groups. There was a higher proportion of males among persons with gunshot wounds (1:9) than those involved in car and motorcycle accidents (1:1.5 and 1:6, respectively). In addition, the group of persons with gunshot wounds was around $12 \%$ younger, than the other groups, with almost half of them having incomplete elementary school/illiterate. Cervical injuries were most frequent in car accidents 
(42.3\%). Regarding motorcycle accident and gunshot wounds, we observed a higher frequency of thoracic injuries (Table 2).

\section{Discussion}

Recent epidemiological reviews have suggested a higher incidence of SCI in the United States (40 cases/million/ year) with 12,400 new cases in 2010 [10]. The worldwide incidence is much lower and may be related to the absence of national records $[10,11]$. There is a higher percentage of men, aged between 15 and 30 years, with cervical and complete lesions owing to traffic accidents [10, 11]. The increasing incidence of SCI in the aging population was also confirmed in studies around the world [10].

According to the 2010 Brazilian National Census, 13 million people had some motor impairment, with $25.5 \%$ of these subjects in the age range between 15 and 49 years. Around $91 \%$ of the population of this study were concentrated in this age range. However, our data cannot be compared with national data as none exists regarding SCI [12].

Our study presents an overview of the spinal cord population admitted to a single hospital system in Brazil. This study covered individuals from all regions of the country, with different social classes. Our results showed a proportion of men and women of 5:1, average age 31, low level of education, mostly with paraplegia, and complete injury. The main causes were gunshot wounds, motorcycle, and car accidents. Persons with gunshots wounds tend to be younger than other causes of injury. No differences were observed in age and level of injury, between gender.

Level of education is not a frequent theme in epidemiological analyses. Our data indicated that men with SCI were mostly illiterate or had incomplete elementary education, whereas most women had completed secondary education. This distribution represents the general population of Brazil, with a higher level of education among women and may also show the fundamental role of education in the prevention of traumatic SCI.

Etiology of SCI in our population deserves a closer look. Gunshot wounds were the main cause of SCI. These data were in agreement with the findings of Koch et al. [13], which showed a frequency of $66 \%$ of cases. Moreover, our findings are consistent with an epidemiological survey of persons with SCI secondary to gunshot wounds in Brazil that showed most individuals were male, with complete thoracic injury [14]. The second leading cause of injury was motorcycle accidents. According to the Brazilian Ministry of Health, in 2013, 51.8\% of all hospital admissions for traffic accidents were related to motorcycles, with an increase of $114 \%$ in 5 years [15]. Behavior regarding alcohol abuse could be considered a risk factor within this context, especially among young people [5]. Aspects related to urban violence, including gunshot wounds and traffic accidents, were associated with SCI in young individuals and paraplegia [10]. These data were in line with this study, which $70 \%$ of the population was under 37 years of age and $68 \%$ of the injuries occurred in the thoracolumbar region.

Regional data collected between 1995 and 2002, reported falls $(38.3 \%)$ as the main etiology, followed by car accidents, gunshot wounds and motorcycle accidents [16]. Moreover, increasing falls from standing height have been reported in conjunction with a gradual aging of the population [8]. However, these data represent information from the Southeastern and Northeast region and may not be representative of the Brazilian population.

For an ideal evaluation of the epidemiology of SCI in Brazil, it would be necessary to create a national database that would provide more accurate information on the number of persons affected by SCI, including those who died even at primary care units.

Epidemiological reviews provide us with information that helps identify specific risk factors for each population, implement measures to prevent SCI, and to allocate resources for patient care. The prevention of the main causes of SCI (gunshot wounds, car, and motorcycle accidents), requires further discussion and integrated policies to combat this still increasing source of SCI in Brazil.

\section{Conclusion}

We observed that SCI affects more men, in the third decade of life and with a low level of education. Primary etiologies were gunshot wounds, motorcycle, and car accidents, with complete paraplegia being the most common condition.

\section{Compliance with ethical standards}

Conflict of interest The authors declare that they have no conflict of interest.

\section{References}

1. Wyndaele M, Wyndaele J-J. Incidence, prevalence and epidemiology of spinal cord injury: what learns a worldwide literature survey? Spinal Cord. 2006;44:523-9.

2. Fitzharris M, Cripps RA, Lee BB. Estimating the global incidence of traumatic spinal cord injury. Spinal Cord. 2013;52:1-6.

3. Cripps RA, Lee BB, Wing P, Weerts E, Mackay J, Brown D. A global map for traumatic spinal cord injury epidemiology: towards a living data repository for injury prevention. Spinal Cord. 2011;49:493-501.

4. Rahimi-Movaghar V, Sayyah MK, Akbari H, Khorramirouz R, Rasouli MR, Moradi-Lakeh M, et al. Epidemiology of traumatic 
spinal Cord Injury in developing countries: a systematic review. Neuroepidemiology. 2013;41:65-85.

5. Sekhon LHS, Fehlings MG. Epidemiology, demographics, and pathophysiology of acute spinal cord injury. Spine (Phila $\mathrm{Pa}$ 1976). 2001;26:S2-S12.

6. Botelho R, Albuquerque L, Bastianello Junior R, Júnior A, Augusto A. Epidemiology of traumatic spinal injuries in Brazil: systematic review/Epidemiologia do trauma raquimedular no Brasil: revisão sistemática. Arq Bras Neurocir. 2014;33:100-6. jun

7. da Paz AC, Beraldo PS, Almeida MC, Neves EG, Alves CM, Khan P. Traumatic injury to the spinal cord. Prevalence in Brazilian hospitals. Paraplegia. 1992;30:636-40.

8. Bellucci CHS, De Castro Filho JE, Gomes CM, De Bessa J, Battistella LR, Rubio De Souza D, et al. Contemporary trends in the epidemiology of traumatic spinal cord injury: changes in age and etiology. Neuroepidemiology. 2015;44:85-90.

9. Kirshblum SC, Burns SP, Biering-Sorensen F, Donovan W, Graves DE, Jha A, et al. International standards for neurological classification of spinal cord injury (Revised 2011). J Spinal Cord Med. 2011;34:535-46.

10. Devivo MJ. Epidemiology of traumatic spinal cord injury: trends and future implications. Spinal Cord. 2012;50:365-72.

11. Singh A, Tetreault L, Kalsi-Ryan S, Nouri A, Fehlings MG. Global prevalence and incidence of traumatic SCI. Clin Epidemiol. 2014;6:309-31.
12. IBGE. Censo Demográfico 2010: Características gerais da população, religião e pessoas com deficiência. Tabela 1.3.1-População residente, por tipo de deficiência, segundo a situação do domicílio e os grupos de idade- Brasil-2010. 2010. https://ww2.ibge.gov.br/ home/estatistica/populacao/censo2010/caracteristicas_religiao_ deficiencia/caracteristicas_religiao_deficiencia_tab_pdf.sht (accessed 11 Oct 2016).

13. Koch A, Graells XS, Zaninelli EM. Epidemiologia de fraturas da coluna de acordo com o mecanismo de trauma: análise de 502 casos. [Epidemiologic study on vertebral fractures: analysis of 502 cases in accordance with the trauma mechanism]. Coluna/Column. 2007;6:18-23.

14. De Araújo FA, Heinrich CB, Cunha MLV, Veríssimo DCA, Rehder R, Pinto CAS, et al. Traumatismo raquimedular por ferimento de projétil de arma de fogo: avaliação epidemiológica. [Spinal Cord trauma by a firearm projectile:epidemiological assessment]. Coluna/Column. 2011;10:290-2.

15. Duarte L PLANO DE PREVENÇÃO. Internações por acidentes de motos mais que dobram em cinco anos. 2015. http://portalsa ude.saude.gov.br/index.php/cidadao/principal/agencia-saude/ 18901-internacoes-por-acidentes-de-motos-mais-que-dobram-emcinco-anos (accessed 11 Oct 2016).

16. Santos EAS, Filho WJS, Possatti LL, Bittencourt LRA, Fontoura EAF, Botelho RV. Epidemiology of severe cervical spinal trauma in the north area of São Paulo City: a 10-year prospective study. Clinical article. J Neurosurg Spine. 2009;11:34-41. 